\title{
Studies on Alum as Milk Coagulating Agent in the Manufacture of Paneer - An Indian Cottage Cheese
}

\author{
H. Dwarakanath ${ }^{1}$, P. Gurumoorthi ${ }^{1}$, K. Jayaraj Rao ${ }^{2, *}$, C.N. Pagote ${ }^{2}$ \\ 1. SRM University, Chennai, India \\ 2. Dairy Technology Section, National Dairy Research Institute (Southern Regional Station), Adugodi, \\ Bangalore - 560 030, India. \\ *E-mail: jaysharm@yahoo.com (Corresponding author)
}

Received: 5 May 2020; Accepted: 29 May 2020; Available online: 25 July 2020

\begin{abstract}
Alum is a white crystalline double sulphate of aluminum and potassium that is commonly used as an astringent. Utilising its protein binding property, alum was studied as coagulating agent of milk in the preparation of paneer. Paneer is a soft variety of cottage cheese very popular in Indian sub-continent, used in various culinary dishes. Its preparation essentially involves acid coagulation of hot milk and pressing of the hot coagulum to form a compact block which is then cooled by immersing in chilled water. Citric acid and vinegar are commonly used as coagulating agents of milk during paneer manufacture. However, when alum was used as a coagulating agent, it was observed that most of the proteins were amalgamated during coagulation process resulting in enhanced yield of paneer. It also resulted in reduced solids losses in whey. However, use of alum resulted in a slight astringency in paneer, hence it was recommended to be used in combination with common coagulant i.e. citric acid. The solids content (losses) in whey were 6.62, 6.08, and $6.32 \%$, respectively for citric acid, alum and citric acid + alum mixture used as coagulating agents. Similarly, the yields of paneer were 16.42, 19.04 and $16.99 \%$. The alum coagulated paneer looked glossy and attractive which was indicated by reflectance values of $83.75 \%$ as against $79 \%$ for control paneer sample. The paneer made by alum coagulation had slightly brittle texture.
\end{abstract}

Keywords: Paneer; Alum; Yield; Texture; Whey; Coagulating agent; Solids losses.

\section{Introduction}

Paneer is a soft variety cheese and very popular dairy product throughout the Indian subcontinent. It is consumed directly in raw form and also used in the preparation of several culinary dishes and snacks after deep fat frying at $160-180^{\circ} \mathrm{C}$. An estimated 3-5\% of India's 187 million tons of milk production is being converted into paneer. Paneer is prepared by coagulation of hot milk using citric acid/vinegar, filtering out the coagulum using muslin cloth, pressing the coagulum for a brief period of time and dipping it in chilled water [1]. Coagulating agent plays an important role in paneer manufacture, because the quality and quantity of the coagulum formed is dependent on its concentration and type. Several coagulants have been tried in paneer manufacture, namely, lemon juice, citric acid, tartaric acid, lactic acid, malic acid, hydrochloric acid, phosphoric acid, acetic acid, fermented milk, sour/ cultured whey, yoghurt and lactic cultures with a view to enhance its quality and yield so that paneer manufacture becomes economically viable for the industry. Calcium lactate has also been used as coagulant $[2,3,4]$. So far, the yield of paneer under industry conditions is $13-15 \%$ using cow milk [5]. The main concern for paneer manufacturers is yield of final product as it has the most impact on the final cost and profitability. Therefore, any attempt to enhance the yield is welcome by the industry.

The dairy industry has accepted citric acid and vinegar as conventional coagulating agents for paneer manufacture, but some non-conventional, low-cost coagulants have been suggested without any loss in its yield and quality, by Sachdeva and Singh [2]. Citric acid and vinegar, result in a cohesive coagulum, while lactic acid results in coagulum with less cohesiveness [6] which might turn brittle during storage. This effect of coagulating agent on the quality of coagulum is dependent on the mechanism of action of coagulating agent. When acid is added to hot milk, the $\mathrm{pH}$ of milk decreases and calcium ions are released from casein moieties [7]. Since calcium, which binds casein micelles to remain in colloidal state, is thus lost, the micelles precipitate forming a soft coagulum. As the acidification progresses, syneresis also increases and the coagulum firms up, subsequently culminating into formation of typical paneer texture. The mechanism of coagulum formation with non-acidic coagulants is not the same as that of acidic coagulating agents. When calcium chloride is added to milk, it disturbs the salt balance [8], casein micelles held in colloidal state by calcium bridges get destabilized resulting in coagulum formation. Similarly when ions are added to milk, they chelate to proteins and result in precipitation without 
decrease in $\mathrm{pH}$. Alum is a non-acidic agent widely used for water purification and in leather industry to purify the effluents [9]. Being colourless, chemically it is a double sulphate of aluminium and potassium [10] and easily available in powder as well as crystal form. When added to water, it binds with impurities and separates them from water, resulting in purification of water. In leather industry, it binds with impurities such as dyes and purifies the effluents [10]. When added to milk, it has been observed that it coagulates the milk leaving a clear whey. Hence, it was thought that alum may act as a god coagulating agent for paneer manufacture. In this study, use of alum for preparation of paneer and its influence on paneer quality is being reported.

\section{Materials and methods}

\subsection{Materials}

Raw cow milk was procured from Institute's Cattle Yard. It was filtered, warmed to about $40^{\circ} \mathrm{C}$ and standardized to $4.0 \%$ fat and $8.5 \%$ SNF. Citric acid (edible grade), vinegar and alum (edible grade) were purchased from the local market.

\subsection{Methods}

\subsubsection{Preparation of paneer}

The standardized milk was heated in a plate heat exchanger (APV make, Kolkata) to about $90^{\circ} \mathrm{C}$ and collected in a vat. It was allowed to cool to about $80^{\circ} \mathrm{C}$. Coagulant solution [a. $2 \%(\mathrm{w} / \mathrm{v})$ citric acid solution and b. $1 \%$ $(\mathrm{w} / \mathrm{v})$ citric acid $+2 \%(\mathrm{w} / \mathrm{v})$ alum- solution] was heated to $80^{\circ} \mathrm{C}$ and slowly added to milk till it coagulated, and clear, greenish whey appeared on surface. In case of alum, (c. the $3 \%$ alum solution) was heat treated to $90^{\circ} \mathrm{C}$ to make it completely soluble in water and this also facilitated lower intake of the coagulant for milk coagulation and the coagulation temperature was maintained at $90^{\circ} \mathrm{C}$. After coagulation, the curds were filtered through muslin cloth to drain off the whey and the curds transferred to hoops lined with muslin cloth and subjected to pressing to obtain a compact block of paneer. A hoop of $15 \mathrm{H} \times 10 \times 10 \mathrm{~cm}$ was used and $45 \mathrm{~g} / \mathrm{cm}^{2}$ pressure was applied for a period of 20 minutes, by placing $4.5 \mathrm{~kg}$ weight on it. Immediately after pressing the paneer was transferred to chilled water $\left(\sim 5^{\circ} \mathrm{C}\right)$ and kept for 45 minutes. Paneer block was then taken out of chilled water, then drained for 2 minutes, cut into $250 \mathrm{~g}$ blocks and packed in polythene pouches ( $65 \mu \mathrm{M}$ thick) for further analysis.

\subsubsection{Yield}

Yield of paneer was determined by recording the weight of coagulum after taking out the coagulum from chilled water and expressed as percentage.

\subsubsection{Solids losses}

Solids losses in whey were indirectly measured by measuring optical density of the latter at 600 nm wave length. The whey obtained during coagulation was collected, cooled to about $30^{\circ} \mathrm{C}$ and volume recorded. Its optical density was measured using spectrophotometer (Bausch and Lomb, New York). Solids losses in whey were also directly measured by estimating total solids content of whey.

\subsubsection{Textural properties}

Textural properties of paneer were determined by performing two-bite Texture Profile Analysis using Texture Analyser (Stable Microsystems, UK) as described by Bourne [11] and Dwarakanath et al. [12]. Paneer was cut into $1.5 \mathrm{~cm}^{3}$ size cubes and tempered to a temperature of $30^{\circ} \mathrm{C}$. Paneer cube was positioned centrally on the heavy duty platform of Texture Analyser below the flat surface of the circular plate type probe (Code no. of the probe: $\mathrm{P} / 75$ ). When the test was commenced, the probe moved down and compressed the cubical sample by $7.5 \mathrm{~mm}$ height (50\% compression) generating force (g) - time (sec) curve which was interpreted in terms of six textural parameters, which included 4 measured (hardness, adhesiveness, springiness, cohesiveness) and two calculated (gumminess and chewiness) attributes (Fig.1). All the tests were replicated three times. The test settings were: load cell capacity $50 \mathrm{~kg}$, platen probe (P/75) of $75 \mathrm{~mm}$ diameter, pretest speed $5 \mathrm{~mm} / \mathrm{sec}$, test speed $1 \mathrm{~mm} / \mathrm{sec}$ and post test speed $2 \mathrm{~mm} / \mathrm{sec}$ and trigger force $5 \mathrm{~g}$.

\subsubsection{Sensory evaluation}

The paneer cubes were tempered to about $30^{\circ} \mathrm{C}$ in an incubator. The tempered samples were served to a panel of trained judges in a sensory evaluation room and evaluation carried out under standard conditions as per BIS [13] guidelines. The judges were asked to carefully examine the samples and score for the overall acceptance on a 9point Hedonic scale [14]. A score of 1.0 on the scale indicated that a particular product attribute was 'disliked extremely' and 9.0 indicated 'liked extremely'. 


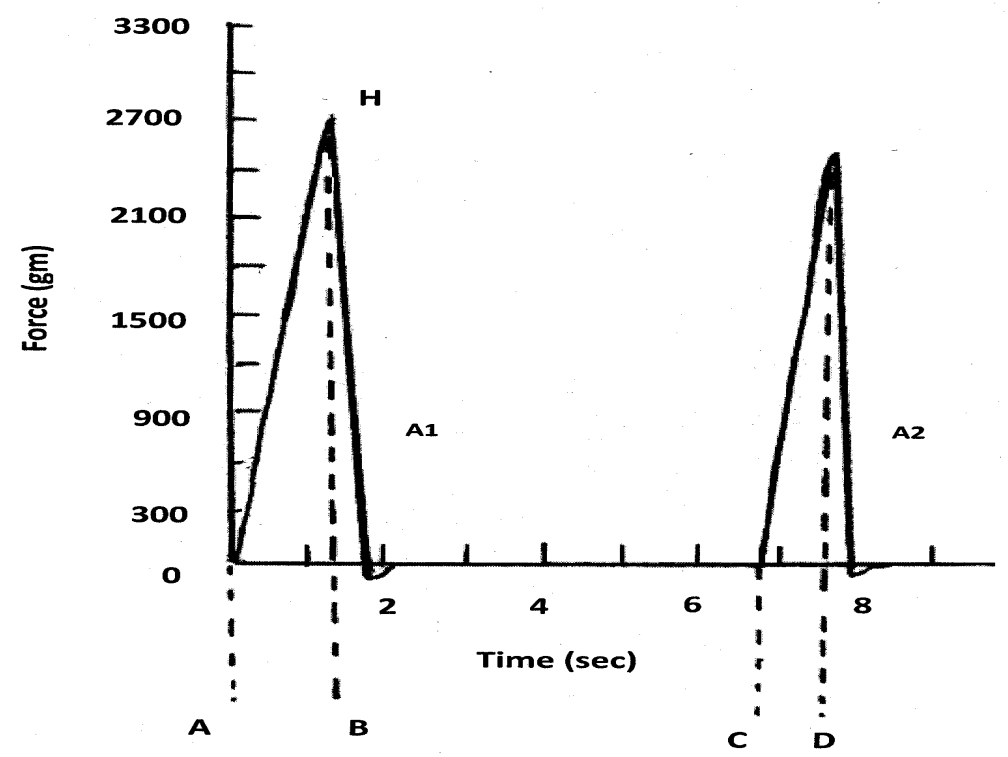

Figure 1. Typical two bite texture profile curve of raw paneer. Calculations: H- Hardness, g (maximum value on first peak); A1 - Area of the first peak, g.sec; A2 - Area of the second peak, g.sec; A - Time at which first bite started, sec; B - Time at which first compression of sample ended, sec; C - Time at which second bite started, sec; D - Time at which second compression of sample ended. Sec; Cohesiveness = A2 / A1; Springiness = C-D / A-B; Gumminess = Hardness x Cohesiveness (g); Chewiness = Gumminess x Springiness (g); Adhesiveness- Area of the first negative peak (g.sec)

\subsubsection{Reflectance}

Reflectance was determined using reflectancemeter ('Elico' - Hyderabad, India) by the method prescribed by manufacturer. The paneer tempered to about $30^{\circ} \mathrm{C}$ was grated and mashed in pestle and mortar and stuffed into a clean, scratch free petri-plate and the bulb of reflecatcemeter was placed on the surface of the plate. The light refelceted by the sample was measured as shown on the dial scale and expressed as per cent refelctance. Measurements were made at 4-6 paces on the petri plate and average of them was epxressed as average reflectance. The higher the reflectance value, whiter is the appearance of the sample and vice versa.

\subsubsection{Chemical analysis}

Standard methods were used for estimation of fat (Mojonnier method), total solids (gravimetric method) and protein (micro-kjeldahl method) contents of whey and paneer [15].

\subsubsection{Statistical analysis}

The sensory evaluation data was subjected to one way analysis of variance as described by Snedecor and Cochran [16] and employing MS Excel package. Where F-test was significant, further analysis was proceeded with the computation of critical difference to know the significant difference between any pair of treatments at $5 \%$ level of significance [17].

\section{Results and discussion}

Preparation of paneer involves the coagulation of milk proteins using permitted acids to form curd. During this process large clumps of proteins are formed in which fat and other colloidal and dissolved solids get entrapped. The coagulation of milk occurs when $\mathrm{pH}$ of milk reaches 4.6 which is the isoelectric point of its major protein, casein, or much before it depending on the coagulation temperature.

\subsection{Effect of alum on chemical parameters of paneer}

Chemical parameters of citric acid coagulated paneer (CAP), alum coagulated paneer (AP) and mixture of citric acid+alum coagulated paneer (MP) are presented in Table 1. Usage of alum for coagulation of milk for paneer manufacture had no significant effect on protein content and ash content of paneer as compared to the control (CAP) as well as the use of combination of both citric acid and alum as coagulant in 1:2 ratios (Table 1).

Fat estimation was also carried out and values were 51.87, 66.81 and 61.38\% on DM (dry matter) basis for CAP, AP and MP, respectively. This fulfills Indian regulatory requirement which states that fat should constitute at least 
$50 \%$ in total solids [18]. Use of alum as a coagulant slightly enhanced the fat content of paneer as compared to that of the control. This is because alum chemicals chelated fine casein particles along with fat globules, which were recovered in paneer coagulum. Similarly, use of mixture of both citric acid \& alum as a coagulant had also a significant effect on fat content of paneer as compared to the paneer prepared from citric acid as a coagulant (Table $1)$.

\subsection{Effect of alum on textural parameters of paneer}

\subsubsection{Hardness}

Paneer manufactured from different coagulants exhibited varying hardness values. Hardness of the paneer samples was found to be 1283.23, 1587.94 and $1838.35 \mathrm{~g}$ for CAP, AP and MP, respectively (Table 2). The hardness of paneer prepared using alum as coagulant was statistically significantly different as compared to that of control but not significantly different as compared to that of the product obtained using the mixture of coagulants. Further, paneer obtained from mixture of coagulants had significantly different in terms of hardness of paneer as compared to control. This shows that paneer prepared from alum was firmer than paneer obtained by using citric acid, and also paneer made from mixture of coagulants was harder compared to paneer from citric acid. But there was no statistically significant difference between alum coagulated paneer and the paneer prepared from mixture of citric acid and alum as coagulant.

Table 1. Effect of alum on chemical parameters of paneer

\begin{tabular}{llll}
\hline Citric acid: Alum ratio & Protein $\%$ & Fat $\% \dagger$ & Ash \% \\
\hline $1: 0$ (only citric acid) & $17.07 \pm 3.8^{\mathrm{a}}$ & $51.87 \pm 2.2^{\mathrm{a}}$ & $1.36 \pm 0.50^{\mathrm{a}}$ \\
$0: 1$ (only alum) & $16.12 \pm 4.5^{\mathrm{a}}$ & $66.81 \pm 4.2^{\mathrm{c}}$ & $1.58 \pm 0.55^{\mathrm{a}}$ \\
$1: 2$ (mixture) & $17.93 \pm 4.5^{\mathrm{a}}$ & $61.38 \pm 3.1^{\mathrm{b}}$ & $1.58 \pm 0.60^{\mathrm{a}}$ \\
\hline
\end{tabular}
basis

Table 2. Effect of alum on textural parameters of paneer

\begin{tabular}{lllllll}
\hline $\begin{array}{l}\text { Citric acid: } \\
\text { Alum ratio }\end{array}$ & $\begin{array}{l}\text { Hardness } \\
(\mathrm{g})\end{array}$ & $\begin{array}{l}\text { Adhesiveness } \\
\text { (g.sec) }\end{array}$ & Cohesiveness & Springiness & $\begin{array}{l}\text { Gumminess } \\
(\mathrm{g})\end{array}$ & $\begin{array}{l}\text { Chewiness } \\
(\mathrm{g})\end{array}$ \\
\hline $1: 0$ (only citric acid) $^{\mathrm{a}}$ & $1283.23 \pm 95^{\mathrm{a}}$ & $12.18 \pm 1.8^{\mathrm{a}}$ & $0.628 \pm 0.09^{\mathrm{a}}$ & $0.879 \pm 0.03^{\mathrm{a}}$ & $797.15 \pm 25^{\mathrm{a}}$ & $701.87 \pm 55^{\mathrm{a}}$ \\
$0: 1$ (only alum) $^{\mathrm{a}}$ & $1587.94 \pm 98^{\mathrm{b}}$ & $8.19 \pm 1.5^{\mathrm{a}}$ & $0.531 \pm 0.03^{\mathrm{a}}$ & $0.905 \pm 0.04^{\mathrm{a}}$ & $859.64 \pm 27^{\mathrm{a}}$ & $780.14 \pm 65^{\mathrm{a}}$ \\
$1: 2$ (mixture) $^{\mathrm{a}}$ & $1838.35 \pm 101^{\mathrm{b}}$ & $11.43 \pm 1.7^{\mathrm{a}}$ & $0.632 \pm 0.09^{\mathrm{a}}$ & $0.889 \pm 0.03^{\mathrm{a}}$ & $1156.58 \pm 29^{\mathrm{b}}$ & $1028.91 \pm 92^{\mathrm{b}}$ \\
\hline
\end{tabular}

Note: Data with similar superscripts in a column are statistically not significant $(\mathrm{p} \geq 0.05)$

\subsubsection{Adhesiveness, springiness and cohesiveness}

The paneer parameters mentioned in this context had closely related values with each other and adhesiveness, cohesiveness and springiness values for CAP, AP and MP were as given in Table 2. Neither the use of alum nor mixture of coagulants in paneer manufacture had any significant effect on the above parameters as compared to use of conventional coagulant citric acid in manufacture of paneer.

\subsubsection{Gumminess \& chewiness}

The gumminess profile for the paneer from CAP, AP and MP were 797.15, 859.64 and 1156.58 g respectively (Table 2) Gumminess a product of hardness and cohesiveness was also closely related among the three varieties of paneer. Use of alum as a coagulant in paneer preparation had no significant effect on gumminess in comparison with the CAP, but incorporation of mixture of coagulants in paneer preparation resulted in significantly different gumminess from the control.

The same result applies for the chewiness also. Chewiness values for CAP, AP and MP were 701.87, 780.14 and 1028.91, g respectively (Table 2). Use of alum as a coagulant in paneer preparation had no significant effect on chewiness in comparison with the CAP, but incorporation of mixture of coagulants in paneer preparation resulted in significantly different chewiness from the CAP. Finally, it may be said that use of alum as a coagulant had a varied effect on textural attributes of paneer, but the texture of the paneer was within the acceptable range, though it resulted in slight granularity and crumbliness. Further, use of both citric acid and alum in combination as a coagulant gave much better texture as compared to the paneer from alum alone, but scored less in textural attribute as compared to the control sample.

The reasons for these observations could be many. It may be traced to the mechanism of colloidal existence of casein micelles itself. In raw milk, native casein micelles are stabilized by net negative charges and steric repulsions [19]. The body and texture development of paneer starts from the heating of raw milk itself. Heat treatment of milk at a temperature starting from $70^{\circ} \mathrm{C}$ initiates denaturation of whey proteins which associate with 
casein micelles involving k-casein via hydrophobic interactions and intermolecular disulphide bonds [20]. These denatured whey proteins because of their sticky nature coat the casein micelles accomplishing casein-whey protein interactions [7]. Denaturation of proteins means opening up of their structural coil because of breakage of intact bonds by heat energy [21]. This leads to the exposure of more number of hydrophilic groups which were earlier embedded inside the structure of native proteins, hence denatured whey proteins bind more strongly to casein micelles. The combination of caseins and denatured whey proteins has better water binding ability, so imparts typical chewy body to the product so that consumer gets smoother but chewy mouthfeel on eating the paneer. During acidification of milk to $\mathrm{pH}$ of 5.3-5.4 during manufacture [22], colloidal calcium phosphate (CCP) in the micelles is solubilised, the charge on individual micelles is altered and the ionic strength of the solution increases. As a result the forces responsible for the integrity of these micelles like CCP-depleted casein particles are considerably different from those in native micelles. The balance between the intermolecular attraction and repulsive forces which is important for gelation properties is also modified [23]. During the subsequent coagulation process, the casein curd particles because of charge neutralization on casein micelles group together as clumps as syneresis progresses, but still remain loosely bound with each other. They are made to tightly bind to each other during subsequent pressing stage under hot conditions to form a unified curd block. The whey protein coating around the casein micelles is still fresh and sticky under hot condition. Hence, before the stickiness is lost, the curd has to be pressed in hot condition so that the curd particles fuse together to form a single block. This step bestows paneer with an integrated body and texture which is retained even after deep frying in oil medium at high temperatures $\left(160-180^{\circ} \mathrm{C}\right)$. This was also probably responsible for the core and lining microstructure reported by Kalab et al. [24]. So, it can be understood that the structure of paneer is mainly casein-whey protein complex in which other ingredients like fat globules, lactose and minerals are embedded. Whey or water may be expected to be entrapped in the capillaries of the proteinous matrix of paneer as reported for other proteinous products by Kinsella and Fox [25]. However, most of the water present in paneer exists as free water, hence the high water activity $\left(\mathrm{a}_{\mathrm{w}}: 0.992\right)[26]$.

Table 3. Effect of alum on yield, total solids recovery, optical density of whey and total solids in whey

\begin{tabular}{lllll}
\hline Citric acid: Alum ratio & Yield (\%) & $\begin{array}{l}\text { Total solid recovery } \\
(\%)\end{array}$ & $\begin{array}{l}\text { Total solids of whey } \\
(\%)\end{array}$ & $\begin{array}{l}\text { Optical } \\
\text { density }\end{array}$ \\
\hline $1: 0$ (only citric acid) & $16.42 \pm 1.10^{\mathrm{a}}$ & $59.07 \pm 2.5^{\mathrm{a}}$ & $6.617 \pm 0.50^{\mathrm{b}}$ & $1.41 \pm 0.13^{\mathrm{b}}$ \\
$0: 1$ (only alum) & $19.04 \pm 2.0^{\mathrm{b}}$ & $64.92 \pm 3.0^{\mathrm{b}}$ & $6.083 \pm 0.40^{\mathrm{a}}$ & $1.02 \pm 0.10^{\mathrm{a}}$ \\
$1: 2$ (mixture) & $16.99 \pm 1.15^{\mathrm{a}}$ & $61.19 \pm 2.6^{\mathrm{a}}$ & $6.315 \pm 0.42^{\mathrm{a}}$ & $1.13 \pm 0.11^{\mathrm{a}}$ \\
\hline
\end{tabular}

Note: Data with similar superscripts in a column are statistically not significant $(\mathrm{p} \geq 0.05)$

When casein-whey protein complex aggregates are larger, more void spaces are formed in the network imparting sponginess to the product. In paneer, the casein micelles are several times larger than those in fresh and heat treated milk. The casein micelle swells from $100 \mathrm{~nm}$ to $300 \mathrm{~nm}$ as a result of heat treatment of milk. Raw cow milk paneer has a uniform density of small protein particles. In contrast, buffalo milk paneer has more densely packed and fused protein particles. Intact fat globule membranes are frequently seen in raw paneer microstructure. The manufacturing process and the milk components such as casein micelles, whey proteins, fat globules, lactose and minerals with additives determine the texture and microstructure of paneer. Microstructure also influences some physical properties of the product such as firmness, elasticity, susceptibility to syneresis and mouthfeel.

\subsection{Effect of alum on yield, total solids recovery and total solids in whey}

\subsubsection{Yield}

Yield, total solids recovery and total solids in whey are interrelated. Yield is the very important parameter that the industry desires and in this study it has been calculated on the weight basis. Yield of paneer from CAP, AP and MP were 16.42, 19.04 and $16.99 \%$ respectively.

Alum showed a significant effect on enhancement of yield, but combining it with citric acid has nullified the effect (Table 3). Usage of alum alone in the long run, may prove to be an excellent yield improver at low costs. Though alum is currently not in the list of permitted coagulants, it is conventionally being used in water purification and decolourisation of paper in paper industry. In this study, we have incorporated alum as a coagulant for milk since it can synergistically change the salt balance in the milk. Conventionally citric acid, acetic acid or vinegar are used as coagulants of milk during paneer production where the yield obtained would be $13-15 \%$ on an industrial scale. Alum usage as a coagulant may be of significance because it improves yield and appearance of paneer. Alum until now has never been used as a coagulant in paneer manufacture. Use of conventional coagulant i.e. citric acid invariably results in losses of solids through whey which becomes the limiting factor for the yield of paneer. In this way, paneer making is considered as marginally profitable. So, this discovery of alum in 
increasing the yield will benefit both the producers and consumers as it has an ability to give an acceptable product with a higher yield which will be shown in the results discussed in the ensuing sections.

The nature of coagulum formed very much depends on the type of acid. This could be attributed to the nature of conjugate base of coagulant formed with caseins during coagulation. Citric acid, acetic acid and lemon juice yield more or less similar curd, but lactic acid yields smoother curd. Kumar et al. [3] studied the use of calcium lactate as a coagulant in paneer manufacture and observed higher yield (21.62\%) than that given by citric acid (18.12\%) and sour whey $(20.17 \%)$ coagulants. The higher yield with calcium lactate was attributed to better moisture retention (61.85\%) and higher TS recovery. The lower yields in the present study could be attributed to use of cow milk. It was also claimed that the sensory quality of paneer manufactured using calcium lactate was better with respect to body and texture and overall acceptability than that manufactured using citric acid and sour whey. Karadbhajne and Bhoyarkar [27] showed that paneer prepared by 2 and $4 \%$ ascorbic acid was better in terms of yield, colour, flavour, taste, and even in terms of shelf life as compared to citric acid, lactic acid and tartaric acid as coagulants. Deshmukh et al. [4] reported that directly acidified whey was suitable as coagulant for paneer making, but cultured whey was not suitable because it yielded soft and loose body and open texture.

\subsubsection{Total solid recovery}

Amount of the solids recovered in the coagulum will tell us how much of solids were wasted through whey and it helps us to optimize the conditions used during coagulation. The values for total solid recovery in percentage for CAP, AP and MP are 59.07, 64.92 and 61.19 respectively. (Table 3)

Alum proves to be an improver in yield of paneer when total solid recovery was calculated. Paneer prepared by utilizing alum as a coagulant was significantly different in the total solids recovery than in the paneer prepared from citric acid as a coagulant. The same result applies for the solid recovery for paneer prepared from mixture of coagulants, where alum overshadows the result of the other two coagulants with reference to total solid recovery in paneer with better results and thereby is favored as a coagulant.

The plausible mechanism seems to be as follows: The particles in milk carry negative charges and alum dissolved in aqueous medium carries positive charges. Thus charges on casein particles are neutralized and flocculation is enhanced. However, one report [28] suggests that alum when used at low doses ( $<5 \mathrm{mg} / \mathrm{ltr})$, charge neutralization (destabilization) is the primary mechanism involved. At higher dosages, as in the present study, the primary coagulation mechanism tends to be entrapment. In this case, aluminum hydroxide $\left[\mathrm{Al}(\mathrm{OH})_{2}\right]$ precipitates forming a "sweepfloc" that tends to capture suspended solids as it settles out of suspension. The pH of the medium plays an important role when alum is used for coagulation because the solubility of the aluminum species in aqueous medium is $\mathrm{pH}$ dependent. Optimum coagulation occurs when negatively charged forms of alum predominate, which occurs when the $\mathrm{pH}$ is between 6 and 8.

\subsubsection{Total solids in whey}

The total solids per cent in whey of CAP, AP and MP were 6.617, 6.083 and 6.315, respectively. (Table 3)

During coagulation, curd is separated out and whey is drained as a waste at the time of paneer manufacture. The solids' loss through whey may be attributed to the crumbly nature of the paneer curd, the fines being lost through whey during filtration. Use of citric acid shows greater loss of solids through whey as indicated by solids\% in whey. Further, the study shows that use of alum as a coagulant for paneer manufacture reduced the solid loss through whey and the loss was significantly lower than in control. Both citric acid and alum were used as a combination in 1:2 ratio which gave better results than that of control in terms of solids loss through whey but this mixture had no significance in reducing the losses of solids through whey in comparison with alum used alone.

\subsubsection{Optical density of whey}

Optical density (OD) of the whey was determined in order to evaluate the opaqueness of the whey which is directly related to solids losses. It was found that whey from CAP had more opaqueness as seen from the Fig. 2. The OD values for CAP, AP and MP were 1.41, 1.02 and 1.13, respectively (Table 3). This method of measuring OD was also reported for water purification wherein decreased absorbance at $254 \mathrm{~nm}$ of water treated with alum was reported [29].

OD of the whey shows the losses of solids through whey due to scattering as well as absorbance of light. The higher the OD means higher are the losses. Appearance of whey from alum paneer was more transparent and greenish than the whey from control (Fig. 2). This shows that due to greater solid losses in whey from control sample, the OD was higher than that of the whey from alum - sample. Further, use of mixture of coagulants for paneer had significant effect on reduction of OD of whey in comparison with that of the control but, had no effect in reduction of solid losses through whey in comparison with the alum sample whey.

Generally whey contains approximately half of the total solids of the original milk. Khamrui and Rajorhia [30] reported 6.4\% losses in paneer whey, while Gupta [31] reported a loss of 6.5\%. According to Bhavsagar et al. [32], 
the total solids content of whey ranged between 6.5 to 7.0 per cent which approximately matches with the value reported in the present work.

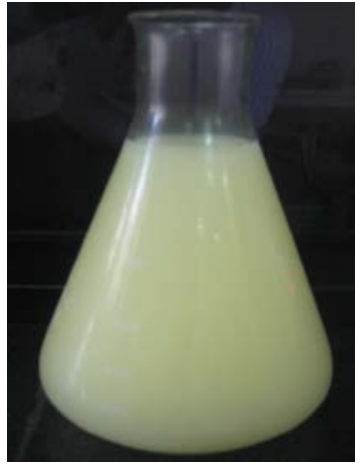

(a)

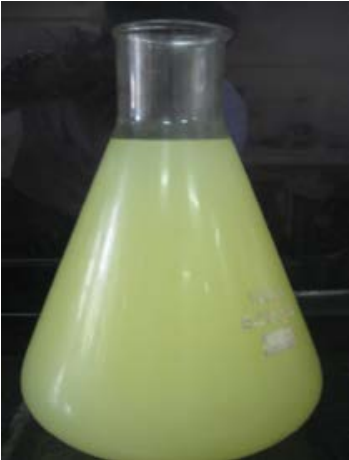

(b)

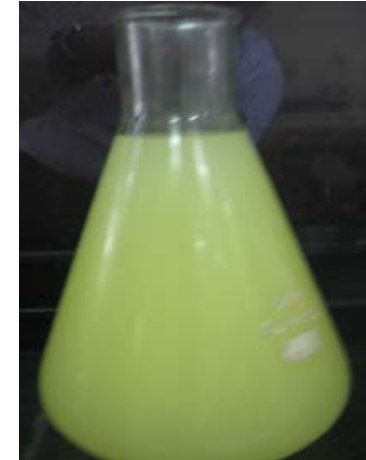

(c)

Figure 2. Whey samples of (a) CAP, (b) MP, (c) AP (decreasing opaqueness from a to c may be noted)

\subsection{Effect of alum on whey volume}

Paneer whey is usually discarded as a waste from dairy industry because of its low protein content. This waste proves to be an additional effluent burden on waste treatment plant. During the present study, whey volume per ltr of milk from control sample was greater than that obtained from paneer preparation using alum. Use of alum as a coagulant in paneer preparation reduced the whey volume significantly in comparison with that of whey from control (Fig 3a). So, this reduces the effluent load considerably and is of greater importance when used on industrial scale. Further, use of mixture of coagulants resulted in significant reduction in whey volume in comparison with that of whey from control but this was not significantly different from that of whey from the alum sample whey.

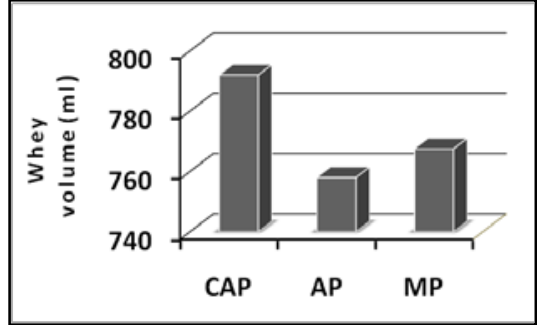

(a)

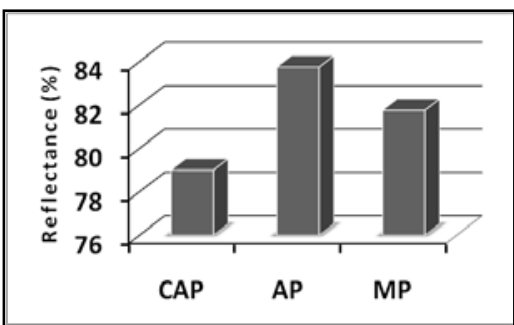

(b)

Figure 3. Effect of alum on (a) whey volume per ltr of milk and (b) reflectance of paneer [CAP - Citric acid coagulated paneer; AP - Alum coagulated paneer; MP - Mixture (alum + citric acid) coagulated paneer]

\subsection{Effect of alum on reflectance of paneer}

Buffalo milk is the main source of paneer preparation in northern parts of sub-continent [33] and buffalo milk gives paneer its characteristic glossy white color. Buffalo milk gives better quality paneer than cow milk because of inherent variation in nature of their proteins [34]. A whiter paneer is always preferred because it resembles the appearance of buffalo milk paneer. Paneer from alum as a coagulant gives glossy white color as in comparison with paneer from cow milk that gives pale creamy white product. This was proven when reflectance of the product was measured using reflectance meter. Reflectance of control paneer (made using citric acid) was 79\%, whereas that for the product made using alum was $83.75 \%$ (Fig.3b). The paneer made using MP was whiter than control sample. It is not clear why alum gives a whiter coagulum, but it may be because of formation, during coagulation process, of aluminium hydroxide which has a glossy white appearance [35].

Good quality paneer is characterized by a white color, sweetish, mildly acidic, nutty flavor, spongy body and closely knit texture. Buffalo milk paneer has all these attributes, hence it is preferred to cow milk paneer which has a very compact body and close texture [36].

\subsection{Effect of alum on sensory acceptance of paneer}

The sensory scores for AP with respect to body and texture were low as compared to that of both CAP and MP (Table 4). But overall acceptability was found to be the same for all the three coagulants used in this study. The overall acceptability values for CAP, AP and MP were 7.42, 7.52 and 7.46 respectively (Table 4). Sensory scores 
for paneer from all the three coagulants were statistically not different but there was some affinity of judges towards CAP body and texture as compared to the AP and MP. Though there was variation in instrumental values, they did not influence sensory acceptance scores because this was based on extent of 'liking ‘. Similar observation was made by Dwarakanath et al [37] with market samples of paneer. Bourne [38] reported that correlation between instrumental parameters and sensory scores is complex and there may not be direct correlation between them.

Table 4. Effect of alum on sensory attributes of paneer

\begin{tabular}{ccccc}
\hline Citric Acid: Alum ratio & $\begin{array}{c}\text { Color \& } \\
\text { appearance }\end{array}$ & $\begin{array}{c}\text { Body \& } \\
\text { texture }\end{array}$ & Flavor & $\begin{array}{c}\text { Overall } \\
\text { acceptability }\end{array}$ \\
\hline $1: 0$ (only citric acid) & $7.58 \pm 0.15$ & $7.61 \pm 0.16$ & $7.61 \pm 0.15$ & $7.42 \pm 0.13^{\mathrm{a}}$ \\
$0: 1$ (only alum) & $7.92 \pm 0.17$ & $7.53 \pm 0.15$ & $7.67 \pm 0.16$ & $7.52 \pm 0.15^{\mathrm{a}}$ \\
$1: 2$ (mixture) & $7.69 \pm 0.16$ & $7.57 \pm 0.15$ & $7.48 \pm 0.14$ & $7.46 \pm 0.13^{\mathrm{a}}$ \\
\hline
\end{tabular}

Note: Data with similar superscripts in a column are statistically not significant $(\mathrm{p} \geq 0.05)$

\section{Conclusion}

Use of alum in paneer making produced a firmer product, but improved its yield, reduced solids losses through whey, enhanced total solid recovery and resulted in a whiter product. Alum usage can be recommended as a coagulant to the dairy industry as it improved yield by $2.5-3 \%$. However, alum is yet to be permitted by Indian Food Safety and Standards Authority. Alum is already widely used in purification of drinking water, so it is expected to pass legal hurdles. Further, this study opens up a scope for use of alum in various other coagulated milk products.

\section{References}

[1] Khan SU, Pal MA. Paneer production: a review. Journal of Food Science Technology. 2011; 48(6):645-660.

[2] Sachdeva S, Singh S. Use of non-conventional coagulants in the manufacture of paneer. Journal of Food Science and Technology. 1987; 24(6): 317-319.

[3] Kumar HA, Ramanjaneyulu G, Venkateshaiah BV. Comparison of three coagulants in the preparation of paneer. Tropical Agricultural Research. 1998; 10(4): 407-412.

[4] Deshmukh DS, Zanjad PN, Pawar VD, Machewad GM. Studies on the use of acidified and cultured whey as coagulant in the manufacture of paneer. International Journal of Dairy Technology. 2009; 62(2): 174-181.

[5] Rao KVSS, Zanjad PN, Mathur BN. Paneer technology—a review. Indian Journal of Dairy Bioscience. 1992; 45(6): 281-291.

[6] Sachdeva S, Singh S. Optimization of processing parameters in the manufacture of paneer. Journal of Food Science and Technology. 1988; 25(3): 142-145.

[7] Webb BH, Johnson AH. Fundamentals of dairy chemistry, $3^{\text {rd }}$ ed. Van Nostrand Reinhold Company, New York.1965.

[8] Jenness R, Patton S. Principles of dairy chemistry. $1^{\text {st }}$ ed. Chapman and Hall, London. 1959.

[9] Symons JM. Plain talk about drinking water. American Water Works Association, Denver, USA. 2010 . p.32.

[10] Glick T. Alum. In: Medieval science, Technology and Medicine, An Encyclopedia. Taylor \& Francis, UK. 2005. p.32.

[11] Bourne MC. Texture profile analysis. Food Technology. 1978; 32: 62- 66, 72.

[12] Dwarakanath H, Gurumoorthi P, Sutariya H, Jayaraj Rao K, Pagote CN. Effect of freezing on the textural attributes of paneer during storage. Indian Journal of Dairy Science. 2013; 66(6): 487-495.

[13] BIS. Guide for sensory evaluation of foods. Part I: Optimum requirements. IS: 6273, Bureau of Indian Standards, Manak Bhavan, Bahadur Shah Jafar Marg, New Delhi, India. 1971.

[14] Lawless HT, Heymann H. Sensory evaluation of food: principles and practices. Springer, New York. 2010. p.326.

[15] BIS. Handbook of food analysis, SP-18 Part XI: Dairy products. Indian Standards Institution, New Delhi. 1981.

[16] Snedecor GW, Cochran WG. Statistical methods, $7^{\text {th }}$ ed. Oxford and IBH Publishing Company, New Delhi.1980.

[17] Sundararaj N, Nagaraju S, Venkataramu MN, Jagannath MK. Design and analysis of field experiments. University of Agricultural Sciences, Bangalore.1972.

[18] FSSAI. Food safety and standards act. Universal Law Publications, New Delhi. 2018.

[19] Walstra P. On the stability of casein micelles. Journal of Dairy Science. 1990; 73: 1965-1979.

[20] Haque Z, Kinsella JE. Interaction between k-casein and b- lactoglobulin: predominance of hydrophilic interactions in the initial stages of complex formation. Journal of Dairy Research. 1988; 55: 67-80. 
[21] Lehninger AL. Biochemistry, Second Edition. Kalyani Publishers, Ludhiana, New Delhi. 1982. P. 142.

[22] Aneja RP, Mathur BN, Chandan RC, Banerjee AK. Heat-acid coagulated products. In: Technology of Indian milk product, Dairy India Yearbook, A Dairy India Publication. New Delhi. 2002. p.133-142.

[23] Lucey JA, Singh H. Formation and physical properties of acid milk gels: a review. Food Research. International. 1997; 30: 529-542.

[24] Kalab M, Gupta SK, Desai HK, Patil GR. Development of microstructure in raw, fried and cooked paneer made from buffalo, cow and mixed milk. Food Microstructure. 1988; 7: 83-91.

[25] Kinsella JE, Fox PF. Water sorption by milk proteins. Bulletin of IDF. 1987; 209: 12-40.

[26] Rao KJ, Patil GR. Development of ready-to-eat paneer curry by hurdle technology. Journal of Food Science and Technology. 1999; 36(1): 37-41.

[27] Karadbhajne SV, Bhoyarkar P. Studies on effect of different coagulant on paneer texture prepared from buffalo milk. International Journal of Pharmacological Technological Research. 2010; 2(3): 1916-1923.

[28] Coagulation. water.me.vccs.edu/exam_prep/coagulation.html. [Accession date: 24.8.2014].

[29] AWWA. Selective alum recovery from water treatment residuals. American Water Works Association, USA. 1997. p.72.

[30] Khamrui K, Rajorhia GS. Making profit from whey. Indian Dairyman. 1998; 50:13-17.

[31] Gupta VK. Overview of processing and utilization of dairy by products. Indian Dairyman. 2000; 52: 55-59.

[32] Bhavsagar MS, Awaz HB, Patange UL. Manufacture of Pineapple flavoured beverage from Chhana whey. Journal of Dairying, Foods and Home Sciences. 2010; 29: $110-113$.

[33] Masud T, Shehla S, Khurram M. Paneer (White cheese) from buffalo milk. Biotechnology and Biotechnological Equipment. 2007; 21(4): 451-452.

[34] Patel DH, Rao KJ. Rheology of paneer - a review. Indian Journal of Dairy Science. 2012; 65(2): 95-105.

[35] Maing IY, Miller I. Curcumin-metal colour complexes. U.S. Patent No. 4,263,333. Washington, DC: U.S. Patent and Trademark Office.1981.

[36] Sachdeva S, Singh S, Kanawjia SK. Recent developments in paneer technology. Indian Dairyman. 1985; 6; 37(11): 501-505

[37] Dwarakanath H, Gurumurthi P, Jayaraj Rao K, Pagote CN. Relation between sensory score and texture profile characteristics of paneer under commercial conditions. Research Journal of Engineering and Technology. 2012; 5 (2): 39-44.

[38] Bourne MC. Food texture and viscosity: concept and measurement. $2^{\text {nd }}$ Ed. Academic Press, New York, USA. 2002. p. 293-299.

(C) 2020 by the author(s). This work is licensed under a Creative Commons Attribution 4.0 International License (http://creativecommons.org/licenses/by/4.0/). Authors retain copyright of their work, with first publication rights granted to Tech Reviews Ltd. 